Check for updates

Cite this: RSC Adv., 2017, 7, 34600

Received 17th June 2017

Accepted 5th July 2017

DOI: $10.1039 / c 7 r a 06749 f$

rsc.li/rsc-advances

\section{Algal biomass from the stable growth phase as a potential biosorbent for $\mathrm{Pb}$ (II) removal from water}

\begin{abstract}
Yinta Li, (D) abc Ling Xia, ${ }^{\text {*ad }}$ Rong Huang, ${ }^{a}$ Chenggong Xia ${ }^{a}$ and Shaoxian Song ${ }^{\text {*ad }}$
In this study, the effect of the growth phase on the $\mathrm{Pb}(॥)$ removal performance from water using Chlorella sp. QB-102 dry biomass was investigated. Optimum biosorption conditions were determined as a function of initial solution $\mathrm{pH}$ and contact time. Freundlich isotherm and pseudo-second-order kinetics models were found to be most applicable to $\mathrm{Pb}(॥)$ adsorption on biomass from each growth phase. The maximum adsorption capacities of $\mathrm{Pb}(॥)$ were found to be 205.5, 298.5 and $171.9 \mathrm{mg} \mathrm{g}^{-1}$ for logarithmic, stable and decline phases of biosorbents, respectively. The FT-IR, XPS and potentiometric titration results showed that the lack of phosphoryl groups caused the lowest adsorption efficiency for the decline phase, and the more effective active sites in carboxyl and higher site concentrations of hydroxyl and phosphoryl functional groups led to most of the bioadsorption occurring during the stable phase. Thus, algal biomass from the stable phase can be used as a potential adsorbent for heavy metal removal from water.
\end{abstract}

\section{Introduction}

With the rapid development of industrialization, plenty of industrial effluents containing heavy metals are discharged into unpolluted natural water bodies. ${ }^{1,2}$ These heavy metals can be accumulated in living organisms, including humans, animals and plants. Unlike organic pollutants, heavy metals are nonbiodegradable and remain in the environment available to cause pollution. ${ }^{1,3}$ Lead is one of the common contaminants, which causes various health hazards. It is harmful to nervous, digestive, blood, endocrine and reproductive systems. ${ }^{2}$ Therefore, the permissible limit of lead in potable water should not exceed $0.01 \mathrm{mg} \mathrm{L}^{-1}$ according to the regulation of the WHO.

Conventional methods for heavy metal removal from wastewater include chemical precipitation, complexation, ion exchange, reverse osmosis, filtration, and coagulation. Nevertheless, these processes are limited by high capital and operational cost. ${ }^{1,4}$ Biosorption has emerged as a potential alternative to conventional methods for the heavy metals removal due to its cost effectiveness, high selectivity and efficiency, and good removal performance. ${ }^{5}$ In the last decades, different sources of biomass, such as bacteria, fungi, and algae have been screened and studied extensively. ${ }^{1,6,7}$ Among them, algae including

${ }^{a}$ School of Resources and Environmental Engineering, Wuhan University of Technology, Luoshi Road 122, Wuhan, Hubei, 430070, China. E-mail: xialing@whut.edu.cn; ssx851215@whut.edu.cn

${ }^{b}$ Doctorado Institucional de Ingeniería y Ciencia de Materiales, Universidad Autonoma de San Luis Potosi, Av. Sierra Leona 530, San Luis Potosi, C.P. 78210, Mexico

'Department of Food Engineering, Weihai Ocean Vocational College, Haiwan South Road 1000, Weihai, Shandong, 264300, China

${ }^{d}$ Hubei Key Laboratory of Mineral Resources Processing and Environment, Luoshi Road 122, Wuhan, Hubei, 430070, China macroalgae and microalgae have been proven to be highly effective, reliable and predictable in the heavy metals removal from aqueous solutions. ${ }^{6,8-10}$ It has been found that algal biomass are rich in organic ligands or functional groups, such as carboxyl, hydroxyl, phosphate, amine groups, and so on. These functional groups play dominant roles in the heavy metals removal. However, most researches mainly concern the potential of algal biomass as adsorbents for heavy metal removal, or the modification of algal biomass for better biosorption of heavy metals. ${ }^{6,8-10}$ Well, with the growth time of algal cells, the biochemical component and also surface properties as well as the biomass concentration from different growth phases can be changed. To the best of our knowledge, there are rare reports focus on the effect of growth phase on the surface properties of algal biomass and further effect on the removal performances of heavy metal.

The objective of this study was to screen the best harvest stage for algal biomass as adsorbent for efficient lead removal from water. Chlorella sp. QB-102, isolated form a lead-zinc tailing wasteland was selected as the research subjective. The study gave detailed analysis of lead adsorption behaviors on algal dry biomass from different growth stages in terms of adsorption isotherms and kinetics experiments. Meanwhile, the effect of growth stage on biomass surface characterization has been investigated. The explanations for adsorption mechanism have been supported by FT-IR, XPS and potentiometric titration.

\section{Materials and methods}

\subsection{Algal-based adsorbents preparation}

Chlorella sp. QB-102 was isolated from the tailing wasteland in Qibo mountain lead-zinc mine, Shanggao, Jiangxi provence in 


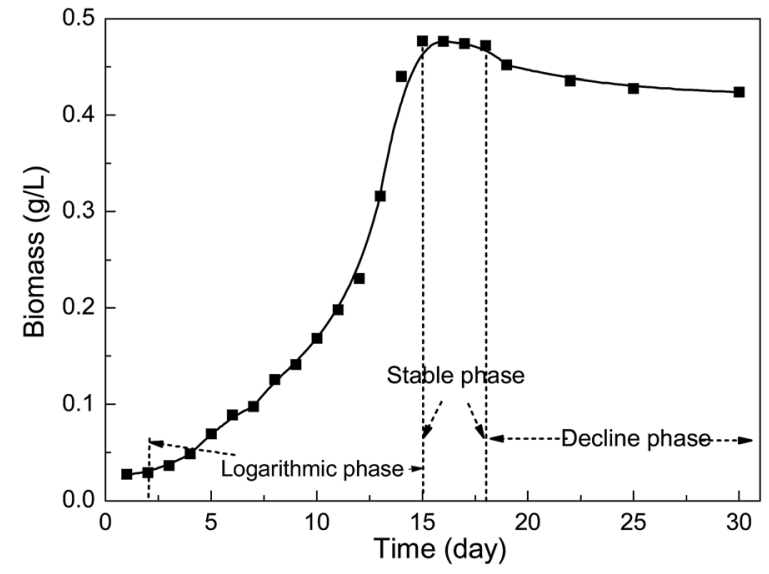

Fig. 1 The growth curve of Chlorella sp. QB-102 in the BG-11 medium

China $\left(28^{\circ} 09^{\prime} \mathrm{N}, 114^{\circ} 52^{\prime} \mathrm{E}\right)$ and identified by classical morphological methods. Stock cultures were grown in BG-11 medium containing $1.5 \mathrm{~g} \mathrm{NaNO}, 30 \mathrm{mg} \mathrm{K}_{2} \mathrm{HPO}_{4}, 36 \mathrm{mg} \mathrm{CaCl} \cdot 2 \mathrm{H}_{2} \mathrm{O}$, $6 \mathrm{mg}$ ammonium citrate monohydrate, $6 \mathrm{mg}$ ammonium ferric citrate, $1 \mathrm{mg}$ EDTA, $2.86 \mu \mathrm{g} \mathrm{H}_{3} \mathrm{BO}_{3}, 1.81 \mu \mathrm{g} \mathrm{MnCl}_{2} \cdot 4 \mathrm{H}_{2} \mathrm{O}, 0.222$ $\mu \mathrm{g} \mathrm{ZnSO}_{4} \cdot 7 \mathrm{H}_{2} \mathrm{O}, 0.39 \mu \mathrm{g} \mathrm{NaMoO}_{4} \cdot 5 \mathrm{H}_{2} \mathrm{O}, 0.079 \mu \mathrm{g} \mathrm{CuSO} \cdot \cdot 5 \mathrm{H}_{2} \mathrm{O}$, $0.050 \mu \mathrm{g} \mathrm{CoCl}_{2} \cdot 6 \mathrm{H}_{2} \mathrm{O}$ in $1 \mathrm{~L}$ sterile distilled water. ${ }^{11}$

For trials, Chlorella sp. QB-102 cells were cultivated in BG11 medium at $25{ }^{\circ} \mathrm{C}$ with a light/dark cycle of $14 \mathrm{~h} / 10 \mathrm{~h}$. Samples were taken every day to measure the biomass concentration. The biomass from exponential (day 14), stable (day 18) and declined phase (day 29) as presented in Fig. 1 was centrifuged harvested, washed three times and then freeze-dried (FD-1B-50, Ouman International Industry Co., Ltd., China) for the subsequential biosorption experiments.

\subsection{Reagents}

A stock solution containing $1000 \mathrm{mg} \mathrm{L}^{-1} \mathrm{~Pb}$ (II) was prepared by $\mathrm{Pb}\left(\mathrm{NO}_{3}\right)_{2}$ in deionized water. All chemicals were of analytical grade and obtained from the Xinyang chemical reagent (China). The $\mathrm{pH}$ of the test solution was adjusted with $0.1 \mathrm{M} \mathrm{HNO}_{3}$ or $0.1 \mathrm{M} \mathrm{NaOH}$. Deionized water was used throughout this study (Millipore Q, USA).

\subsection{Biosorption experiments}

The adsorption experiments of $\mathrm{Pb}$ (II) were implemented in triplicate in $100 \mathrm{~mL}$ Erlenmeyer flasks with $50 \mathrm{~mL}$ of $\mathrm{Pb}$ (II) solution combined with $10 \mathrm{mg}$ of adsorbents in a mechanical shaker at the speed of $180 \mathrm{rpm}$ at $25^{\circ} \mathrm{C}$. The influence of $\mathrm{pH}$ on $\mathrm{Pb}$ (II) adsorption was conducted within a $\mathrm{pH}$ range of 2 to 6 at an initial $\mathrm{Pb}$ (II) concentration of $100 \mathrm{mg} \mathrm{L}^{-1}$ for $6 \mathrm{~h}$. Biosorption isotherm experiments were performed by ranging the initial concentration of $\mathrm{Pb}$ (II) from 10 to $300 \mathrm{mg} \mathrm{L}^{-1}$ at $\mathrm{pH} 5.5$ for $6 \mathrm{~h}$. The kinetic experiments were studied by varying contact time intervals in the range of $0.5-300 \mathrm{~min}$ at an initial $\mathrm{Pb}$ (II) concentration of $100 \mathrm{mg} \mathrm{L}^{-1}$ at $\mathrm{pH}$ 5.5. Afterwards, the mixture was filtered through $0.22 \mu \mathrm{m}$ filter membrane and the supernatant was used for $\mathrm{Pb}(\mathrm{II})$ determination.

\subsection{Analytical methods}

2.4.1 Biomass measurement. Generally, the dried cell weight of microalgae is correlated to the optical density (OD) at certain wavelength from 450 to $680 \mathrm{~nm} .{ }^{12}$ In this study, the biomass concentration (BC, $\mathrm{g} \mathrm{L}^{-1}$ ) of Chlorella sp. QB-102 was determined by measuring the optical density of $680 \mathrm{~nm}\left(\mathrm{OD}_{680}\right)$ via an ultraviolet photospectrometer (Shimadzu UV-2550, Japan) as following eqn (1).

$$
\mathrm{BC}=0.255 \times \mathrm{OD}_{680}\left(R^{2}=0.9986\right)
$$

2.4.2 $\mathrm{Pb}$ (II) determination. The concentration of $\mathrm{Pb}$ (II) was determined using an atomic absorption spectrometry (ZEEnit700, Analyjena, Germany) at $283.3 \mathrm{~nm}$. The biosorption capacity of $\mathrm{Pb}(\mathrm{II})$ was calculated by the following eqn (2): ${ }^{13}$

$$
q_{\mathrm{e}}=\frac{V\left(C_{0}-C_{t}\right)}{M}
$$

where $q_{\mathrm{e}}\left(\mathrm{mg} \mathrm{g}^{-1}\right)$ is the equilibrium biosorption capacity of $\mathrm{Pb}(\mathrm{II}) ; C_{0}\left(\mathrm{mg} \mathrm{L}^{-1}\right)$ and $C_{t}\left(\mathrm{mg} \mathrm{L}^{-1}\right)$ are the initial and final concentrations of $\mathrm{Pb}(\mathrm{II})$, respectively; $V(\mathrm{~L})$ is the volume of mixture; $M(\mathrm{~g})$ is the weight of the adsorbent.

2.4.3 Zeta potential measurement. A Malvern Zetasizer Zeta-Nano (England) working with laser doppler electrophoresis technique was employed to determine the zeta potentials of the biosorbents as a function of $\mathrm{pH}$ within 2 to 7 .

2.4.4 XPS analysis. The XPS spectrum (PHI-3056, PerkinElmzr, US) was used to analysis the adsorbents before and after $\mathrm{Pb}(\mathrm{II})$ loading.

2.4.5 Potentiometric titration. Potentiometric titration (PT) was used to determine the deprotonation constants and absolute concentrations of the specific functional groups present on the algal cell walls. ${ }^{14}$ The potentiometric measurements were performed at $25 \pm 0.3{ }^{\circ} \mathrm{C}$ by a glass electrode (Sartorius $\mathrm{pH}$ meter, Germany). The suspension $\mathrm{pH}$ was firstly acidified to 2.5 under constant magnetic stirring (150 rpm). Then titration was performed by stepwise addition of $0.01 \mathrm{~mL}$ of $0.1 \mathrm{M} \mathrm{NaOH}$ to the cell and titrated up to $\mathrm{pH} 10$ while the suspension was stirred under nitrogen protection. Titration data were fitted using a software Profit 2.1 based on the Donnan Shell Model. ${ }^{15,16}$

\subsection{Isotherm and kinetics modelling}

Langmuir (eqn (3)), ${ }^{17}$ Freundlich (eqn (5)) ${ }^{18}$ and Temkin (eqn (6) $)^{13}$ models were used to fit the biosorption data.

$$
q_{\mathrm{e}}=\frac{q_{\mathrm{max}} K_{\mathrm{L}} C_{\mathrm{e}}}{1+K_{\mathrm{L}} C_{\mathrm{e}}}
$$

where $C_{\mathrm{e}}\left(\mathrm{mg} \mathrm{L}^{-1}\right)$ is the equilibrium concentration of $\mathrm{Pb}$ (II) solution; $q_{\mathrm{e}}\left(\mathrm{mg} \mathrm{g}^{-1}\right)$ and $q_{\max }\left(\mathrm{mg} \mathrm{g}^{-1}\right)$ are the amount of $\mathrm{Pb}$ (II) equilibrium adsorbed capacity and the maximum monolayer biosorption capacity of $\mathrm{Pb}(\mathrm{II})$, respectively; $K_{\mathrm{L}}\left(\mathrm{L} \mathrm{mol}^{-1}\right)$ represents the Langmuir model constant which related to the heat of biosorption.

$R_{\mathrm{L}}$, a dimensionless constant as separation factor or equilibrium parameter, can determine whether the essential 
biosorption characteristics of the Langmuir isotherm is favorable or unfavorable, defined as following: ${ }^{17}$

$$
R_{\mathrm{L}}=\frac{1}{1+K_{\mathrm{L}} C_{0}}
$$

where $C_{0}\left(\mathrm{mg} \mathrm{L}^{-1}\right)$ is the highest initial concentration of $\mathrm{Pb}(\mathrm{II})$. $R_{\mathrm{L}}$ indicates the type of Langmuir isotherm to be irreversible $\left(R_{\mathrm{L}}\right.$ $=0)$, favorable $\left(0<R_{\mathrm{L}}<1\right)$, linear $\left(R_{\mathrm{L}}=1\right)$ or unfavorable $\left(R_{\mathrm{L}}>1\right)$.

$$
q_{\mathrm{e}}=K_{\mathrm{F}} C_{\mathrm{e}}^{1 / n}
$$

where $K_{\mathrm{F}}\left(\mathrm{mol}^{1-n} \mathrm{~L}^{n} \mathrm{~g}^{-1}\right)$ represents the biosorption equilibrium constant related to the biosorption capacity; $n$ represents a constant related to the biosorption intensity to be good $(2<n<$ $10)$, moderately difficult $(1<n<2)$, poor sorption characteristics $(n<1) .^{3}$

$$
q_{\mathrm{e}}=A+B \ln C_{\mathrm{e}}
$$

where $A\left(\mathrm{mg} \mathrm{g}^{-1}\right)$ and $B\left(\mathrm{~J} \mathrm{~mol}^{-1}\right)$ are the Temkin constants.

The kinetic parameters were evaluated by using the pseudofirst order (eqn (7)), ${ }^{19}$ pseudo-second-order (eqn (8)), ${ }^{20}$ intraparticle diffusion (eqn (9) $)^{21}$ models, the initial sorption rate (eqn (10)) and the half-sorption time (eqn (11)) $)^{22,23}$ expressed as follows:

$$
\begin{gathered}
\ln \left(q_{\mathrm{e}}-q_{t}\right)=\ln q_{\mathrm{e}}-k_{1} t \\
\frac{t}{q_{t}}=\frac{1}{k_{2} q_{\mathrm{e}}^{2}}+\frac{t}{q_{\mathrm{e}}} \\
q_{t}=C+k_{n} t^{0.5} \\
h=k_{2} q_{\mathrm{e}}^{2} \\
t_{1 / 2}=\frac{1}{k_{2} q_{\mathrm{e}}}
\end{gathered}
$$

where $q_{t}\left(\mathrm{mg} \mathrm{g}^{-1}\right)$ represents the amount of $\mathrm{Pb}$ (II) adsorbed at time $t(\mathrm{~min}), q_{\mathrm{e}}\left(\mathrm{mg} \mathrm{g}^{-1}\right)$ represents the biosorption capacity at equilibrium time, $k_{n}$ represents the rate constant of intraparticle diffusion, $k_{1}\left(\mathrm{~min}^{-1}\right)$ and $k_{2}\left(\mathrm{~g} \mathrm{mg}^{-1} \mathrm{~min}^{-1}\right)$ represents the rate constants for pseudo-first-order and pseudo- second-order, respectively, $h\left(\mathrm{mg} \mathrm{g}^{-1} \mathrm{~min}^{-1}\right)$ represents the initial sorption rate of $\mathrm{Pb}(\mathrm{II}), t_{1 / 2}(\mathrm{~min})$ represents the time needed to adsorb half of the equilibrium value of $\mathrm{Pb}(\mathrm{II})$.

\section{Results and discussion}

\subsection{Influences of growth phase on $\mathrm{Pb}$ (II) biosorption}

3.1.1 Effect of initial solution pH. pH not only affects the dissociation degree of functional groups on biomass surface but also the speciation and solubility of metal ions, and further affects the uptake capacity of metal ions onto the biomass. ${ }^{23}$ In this study, the initial solution $\mathrm{pH}$ was adjusted within a range from 2.0 to 6.0 to investigate the effect of $\mathrm{pH}$ on $\mathrm{Pb}$ (II) adsorption as presented in Fig. 2a. It showed that the biosorption capacity of $\mathrm{Pb}$ (II) on algal biomass increased with increasing $\mathrm{pH}$, and the retention of $\mathrm{Pb}(\mathrm{II})$ is highest at $\mathrm{pH}$ of 5.5 for the algal biomass from all three growth phases. After this $\mathrm{pH}$ value, the biosorption capacity decreased as the $\mathrm{pH}$ increases for all cases, which may be caused by the change of the speciation of lead during the secondary hydrolysis processes. ${ }^{6}$ It was also noted that within the studied $\mathrm{pH}$ range, algal dry biomass from stable phase showed the highest adsorption capacity, followed by exponential and declining phases.

Fig. $2 \mathrm{~b}$ shows the zeta potential of algal biomass from three growth phases as a function of $\mathrm{pH}$. The zeta potential of algal biomass from all the growth phases was negatively charged within the $\mathrm{pH}$ range from 2.0 to 7.0 , and the net zeta potential increased with $\mathrm{pH}$ increasing. Thus, at $\mathrm{pH} 2.0$ where the ionization degree of superficial functional groups of biomass in terms of zeta potential is lower, the biosorption capacity of $\mathrm{Pb}$ (II) was lower. Meanwhile, the increase in the initial solution resulted in the increase of net negatively charged biomass surface, in consequence the number of electrostatic interactions increased. The stable phase biomass showed the lowest net negative surface charge when $\mathrm{pH}$ was above 2 , which can explain that the lowest biosorption capacity of $\mathrm{Pb}$ (II) compared with that from other two growth phases. In addition, at $\mathrm{pH}$ values higher than 5.5 , the decrease in biosorption capacity probably due to conversion of $\mathrm{Pb}$ (II) ions to hydroxylated complexes of $\mathrm{Pb}(\mathrm{II})$, resulting into hydroxide precipitation.
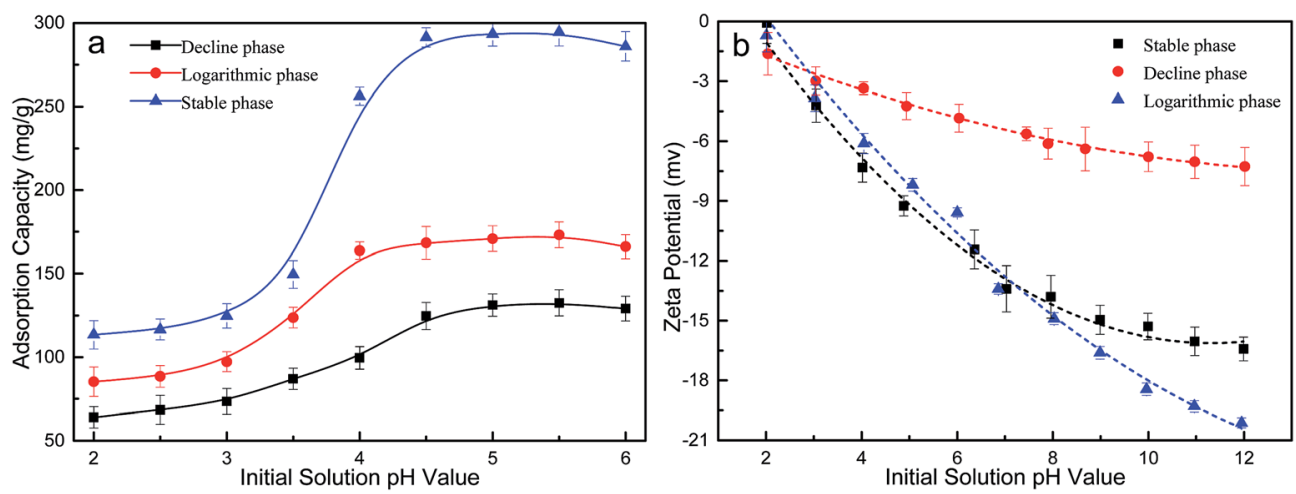

Fig. 2 The effect of the initial solution $\mathrm{pH}$ values on the adsorption capacity (a) and zeta potential as a function of $\mathrm{pH}$ (b) of dried Chlorella sp. QB-102 biomass of each growth phase (initial $\mathrm{Pb}(॥)$ concentration of $100 \mathrm{mg} \mathrm{L}^{-1}, 25^{\circ} \mathrm{C}$ ). 


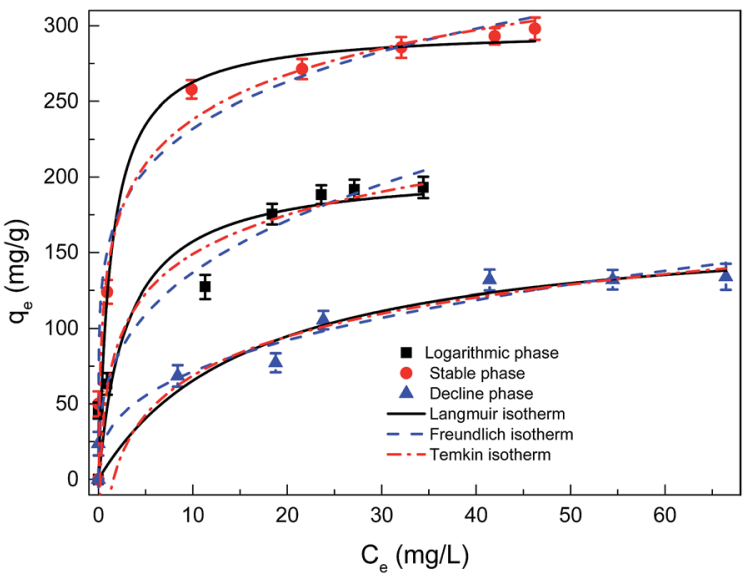

Fig. 3 Adsorption isotherms of dried Chlorella sp. QB-102 biomass of each growth phase, the experimental data were fitted with Langmuir, Freundlich and Temkin models $\left(25^{\circ} \mathrm{C}, \mathrm{pH} 5.5\right.$ for 6 h).

Consequently, an initial solution $\mathrm{pH}$ of 5.5 was considered as the optimum value and was used in all the following experiments.

3.1.2 Biosorption isotherm. The biosorption isotherm models are useful for expressing the surface properties and metal binding behaviors of biosorbent. In this study, three isotherm models were selected to fit the experimental data, namely Langmuir, Freundlich and Temkin models. Fig. 3 illustrates the adsorption capacity of $\mathrm{Pb}$ (II) on dried Chlorella sp. QB-102 biomass from three growth phases as a function of initial $\mathrm{Pb}$ (II) concentration. The biosorption capacities of algal biomass from all the growth phases increased with increasing $\mathrm{Pb}$ (II) equilibrium concentration until reached plateaus. These data were further fitted to Langmuir, Freundlich and Temkin models, and the results were given in Table 1 . These results all suggested that the biosorption isotherm of $\mathrm{Pb}(\mathrm{II})$ onto the dried Chlorella sp. biomass of each growth phase belonged to the Freundlich model in terms of the highest linear regression coefficient $\left(R^{2}\right)$. Freundlich isotherm data showed multilayer deposition of lead ion species on algal surface. ${ }^{\mathbf{6} 24}$

As shown in Table 1 , the $K_{\mathrm{F}}$ value $\left(153.1 \mathrm{~L} \mathrm{~g}^{-1}\right)$ of $\mathrm{Pb}$ (II) adsorbed on the dried Chlorella sp. QB-102 biomass from stable phase was significantly higher than that from logarithmic phase $\left(61.8 \mathrm{~L} \mathrm{~g}^{-1}\right)$ or decline phase $\left(30.7 \mathrm{~L} \mathrm{~g}^{-1}\right)$. Correspondingly, the highest maximum biosorption capacity was also obtained at stable phase from Langmuir fitting, valued at $298.2 \mathrm{mg} \mathrm{g}^{-1}$, which was 1.5 times higher against that at exponential phase (205.5 $\mathrm{mg} \mathrm{g}^{-1}$ ) and 1.8 times against that at declining phase $\left(171.9 \mathrm{mg} \mathrm{g}^{-1}\right)$. The largest biosorption capacity was higher than most biosorbents as listed in Table 2 . These results indicated that the biomass from stable growth phase showed the best performances as an adsorbent for $\mathrm{Pb}$ (II) removal from water.

3.1.3 Biosorption kinetics. The adsorption capacity of $\mathrm{Pb}$ (II) on dried Chlorella sp. QB-102 biomass from three growth phases as a function of time were studied and shown in Fig. 4a. At each growth phase, the $\mathrm{Pb}$ (II) biosorption efficiency increased rapidly and more than $85 \%$ of biosorption was accomplished within $5 \mathrm{~min}$. Then, the biosorption capacity increased slowly until $30 \mathrm{~min}$ and further increasing time to $300 \mathrm{~min}$ showed no obvious changes due to the decreasing number of biosorption sites available on the biosorbent surface. As expected, the biosorption capacity of $\mathrm{Pb}$ (II) on dried stable stage biomass was the highest at any time during the biosorption process compared to the exponential or decline stages.

The experimental data were further fitted to the pseudo-firstorder, pseudo-second order and intra-particle diffusion models. Linear plots of $\log \left(q_{\mathrm{e}}-q_{t}\right)$ versus $t, t / q_{t}$ versus $t$ and $q_{t}$ against $t^{0.5}$ were illustrated in Fig. $4 \mathrm{~b}-\mathrm{d}$, and the associated kinetic parameters and the corresponding linear regression $R^{2}$ were summarized in Table 3 . It showed that the experimental data were best fitted with the pseudo-second-order model according to $R^{2}$ for biomass from all three growth phases. It was suggested that the biosorption of $\mathrm{Pb}$ (II) on the algal biomass was chemisorption.

In addition, it was worth mentioning that the biosorptive capacity of $\mathrm{Pb}$ (II) on dried Chlorella sp. QB-102 biomass of the stable phase is faster than those of the logarithmic and decline phase based on the $h$ and $t_{1 / 2}$ values (Table 3 ). The $h$ and $q_{\mathrm{e}}$ values of dried Chlorella sp. QB-102 biomass of the stable phase were more than 3 times and 1.5 times higher than those of the logarithmic and decline phase, respectively.

Given that the algal biomass from stable phase for $\mathrm{Pb}$ (II) removal showed the best performances in terms of higher biosorption capacity and shorter reaction time, it was recommended that the harvesting operation can be implemented when the algal cells grow to a stable stage when using as algalbased adsorbents.

\subsection{FT-IR spectroscopy}

The FT-IR spectra of biosorbents from three growth stages are shown in Fig. 5a. The broad and intense adsorption band at around $3303 \mathrm{~cm}^{-1}$ was attributed to the bending vibration of the water molecule and - $\mathrm{OH}$ stretching frequency in carbohydrates, protein and lipids. ${ }^{4}$ The peaks at around 2924 and 1458

Table 1 Langmuir, Freundlich and Temkin constants related to the adsorption isotherms of Pb(II) onto dried Chlorella sp. QB-102 of each growth phase

\begin{tabular}{|c|c|c|c|c|c|c|c|c|c|}
\hline & \multicolumn{3}{|l|}{ Langmuir } & \multicolumn{3}{|l|}{ Freundlich } & \multicolumn{3}{|c|}{ Temkin } \\
\hline Stable phase & 298.2 & 0.738 & 0.9912 & 153.13 & 0.181 & 0.9957 & 100 & 42.56 & 0.8939 \\
\hline Decline phase & 171.9 & 0.061 & 0.9761 & 30.71 & 0.367 & 0.9861 & -20 & 37.35 & 0.8861 \\
\hline
\end{tabular}


Table 2 Comparison of the adsorption capacity of $\mathrm{Pb}(॥)$ in this study with other biosorbents

\begin{tabular}{|c|c|c|c|c|}
\hline Adsorbent & $\mathrm{pH}$ & $\begin{array}{l}\text { Adsorption capacity } \\
\left(\mathrm{mg} \mathrm{g}^{-1}\right)\end{array}$ & Contact time & References \\
\hline Pelvetia canaliculata & 5.0 & 300.1 & $100 \mathrm{~h}$ & $\begin{array}{l}\text { (Costa, Vilar, Botelho, } \\
\text { da Silva, \& Boaventura, 2010) }\end{array}$ \\
\hline Algal strains & $3.0-5.0$ & $50-208$ & $30 \mathrm{~min}$ & $\begin{array}{l}\text { (Romera, González, Ballester, } \\
\text { Blázquez, \& Muñoz, 2007) }\end{array}$ \\
\hline Sargassum sp. & 5 & 240.3 & $60 \mathrm{~min}$ & (Sheng, Ting, Chen, \& Hong, 2004) \\
\hline Bacillus sp. L14 & $5.0-5.5$ & 280.02 & $5 \mathrm{~min}$ & (Luo et al., 2014) \\
\hline Cabbage waste & $6.0-6.5$ & $40.963-50.216$ & $3 \mathrm{~h}$ & (Hossain et al., 2014) \\
\hline $\mathrm{Fe}_{3} \mathrm{O}_{4}$-treated waste litchi peel & 6.0 & 78.74 & $120 \mathrm{~min}$ & (R. Jiang et al., 2015) \\
\hline Chlorella sp. QB-102 & $5.5 \pm 0.3$ & 297.1 & $5 \mathrm{~min}$ & This study \\
\hline
\end{tabular}
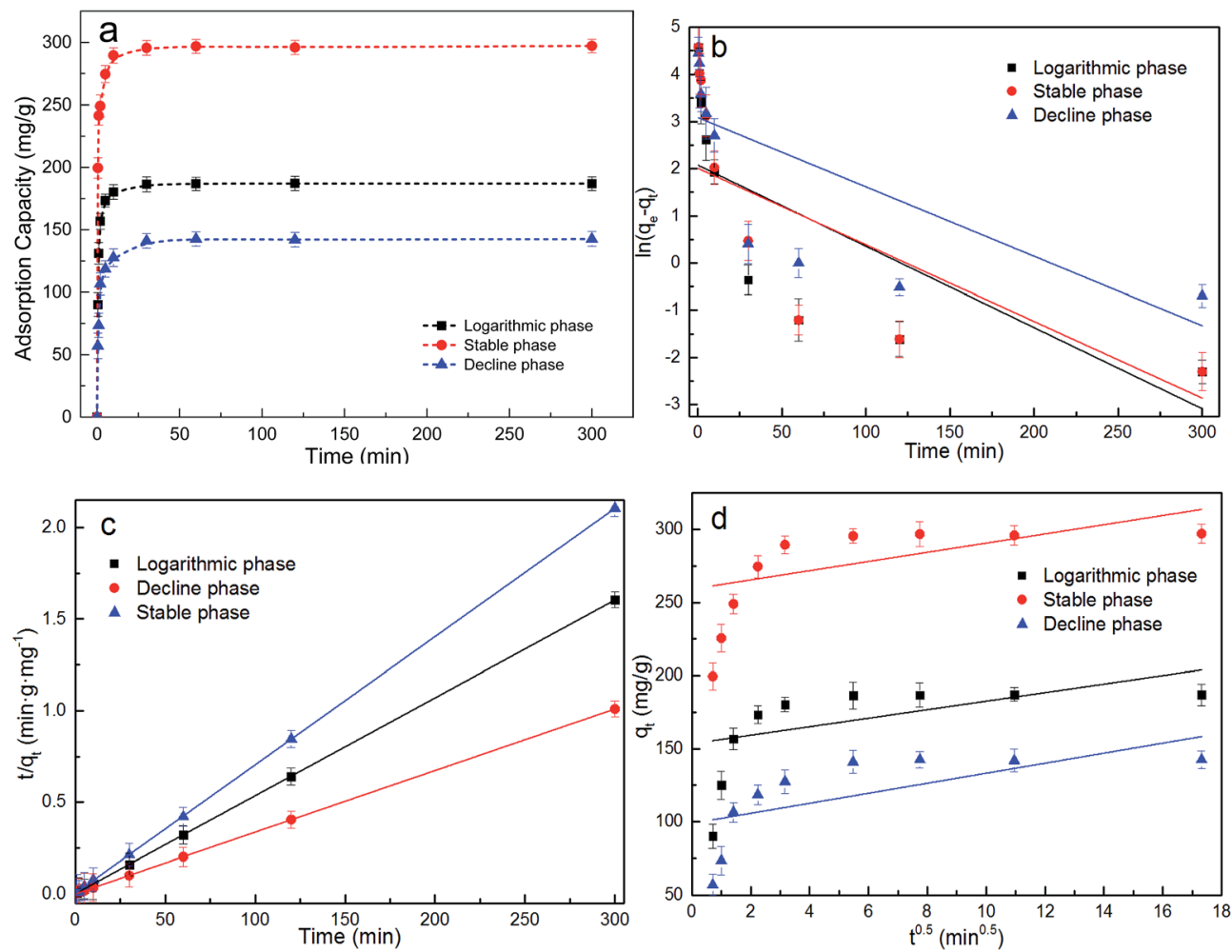

Fig. 4 Effect of contact time on the $\mathrm{Pb}(॥)$ adsorption capacity on biomass of each growth phase (a). The pseudo-first-order model (b), pseudosecond-order model (c), and intra-particle diffusion model (d) sorption kinetics curves were fitted with experimental data (initial Pb(॥) concentration of $100 \mathrm{mg} \mathrm{L}^{-1}, 25^{\circ} \mathrm{C}, \mathrm{pH} 5.5$ for $6 \mathrm{~h}$ ).

$\mathrm{cm}^{-1}$ were assigned to the asymmetric stretching bands of carboxylates groups. ${ }^{20}$ The peaks at $1610-1634 \mathrm{~cm}^{-1}$ was assigned to $\mathrm{C}=\mathrm{C}$ stretching mode from peptide of amide $\mathrm{I}^{25}$ The above functional groups were all present in the biosorbents from the three growth stages. However, it was worth mentioning that the characteristic features were the peaks at 1248 and 1080 $\mathrm{cm}^{-1}$ only presented in the biomass from logarithmic and stable phases, attributed to the $\mathrm{P}=\mathrm{O}$ stretching bands. ${ }^{15,26}$

After biosorption of $\mathrm{Pb}(\mathrm{II})$, the broad peaks shifted from 3387 to $3405 \mathrm{~cm}^{-1}$ for the biomass from all three growth phases, which might be attributed to the complexation of $\mathrm{Pb}$ (II) with free or bonded $-\mathrm{OH}$ groups (Fig. $5 \mathrm{~b}-\mathrm{d}$ ). The variation in peaks at 1744 and $1247 \mathrm{~cm}^{-1}$ in algal biomass of logarithmic growth phase represented $-\mathrm{C}=\mathrm{O}$ groups in carboxylic acids and phosphate groups stretching vibration due to complexation of $\mathrm{Pb}$ (II) with these sites. As for the stable phases, besides variations of $-\mathrm{C}=\mathrm{O}$ and $-\mathrm{P}=\mathrm{O}$ groups, a shift of peak at $1458 \mathrm{~cm}^{-1}$ was observed, which considerably might be due to the complexation between $\mathrm{Pb}$ (II) and $-\mathrm{COOH}$ groups. In contrast, the decline phase lacking phosphate groups showed a variation peaks located at 1623 and $1428 \mathrm{~cm}^{-1}$, which might be attributed to the reaction between $\mathrm{Pb}$ (II) with $-\mathrm{C}=\mathrm{O}$ and $-\mathrm{COOH}$ groups. It can 
Table 3 Parameters of pseudo-first-order, pseudo-second-order, intra-particle diffusion models

\begin{tabular}{|c|c|c|c|c|c|c|c|c|c|c|c|c|}
\hline & \multicolumn{4}{|c|}{ Pseudo-first-order kinetics } & \multicolumn{5}{|c|}{ Pseudo-second-order kinetics } & \multicolumn{3}{|c|}{ Intra-particle diffusion model } \\
\hline & $\begin{array}{l}q_{\mathrm{e}, \exp } \\
\left(\mathrm{mg} \mathrm{g}^{-1}\right)\end{array}$ & $\begin{array}{l}q_{\mathrm{e}, \mathrm{cal}} \\
\left(\mathrm{mg} \mathrm{g}^{-1}\right)\end{array}$ & $\begin{array}{l}k_{1} \\
\left(\min ^{-1}\right)\end{array}$ & $R^{2}$ & $\begin{array}{l}q_{\mathrm{e}, \mathrm{cal}} \\
\left(\mathrm{mg} \mathrm{g}^{-1}\right)\end{array}$ & $\begin{array}{l}k_{2} \\
\left(\min ^{-1}\right)\end{array}$ & $R^{2}$ & $\begin{array}{l}h \\
\left(\mathrm{mg} \mathrm{g}^{-1} \min ^{-1}\right)\end{array}$ & $\begin{array}{l}t_{1 / 2} \\
(\mathrm{~min})\end{array}$ & $\begin{array}{l}K_{n} \\
\left(\mathrm{mg} \mathrm{g}^{-1} \min ^{-1}\right)\end{array}$ & $C$ & $R^{2}$ \\
\hline Logarithmic phase & 187.1 & 182.3 & 1.222 & 0.6736 & 188.8 & 0.0111 & 1 & 395.6 & 0.4772 & 16.55 & 12.074 & 0.2294 \\
\hline Stable phase & 297.1 & 287.8 & 2.001 & 0.7217 & 295.7 & 0.0128 & 1 & 1119 & 0.2642 & 25.63 & 19.71 & 0.2722 \\
\hline Decline phase & 142.5 & 136.7 & 0.813 & 0.6970 & 142.6 & 0.0088 & 1 & 179.0 & 0.7968 & 11.47 & 7.51 & 0.3841 \\
\hline
\end{tabular}
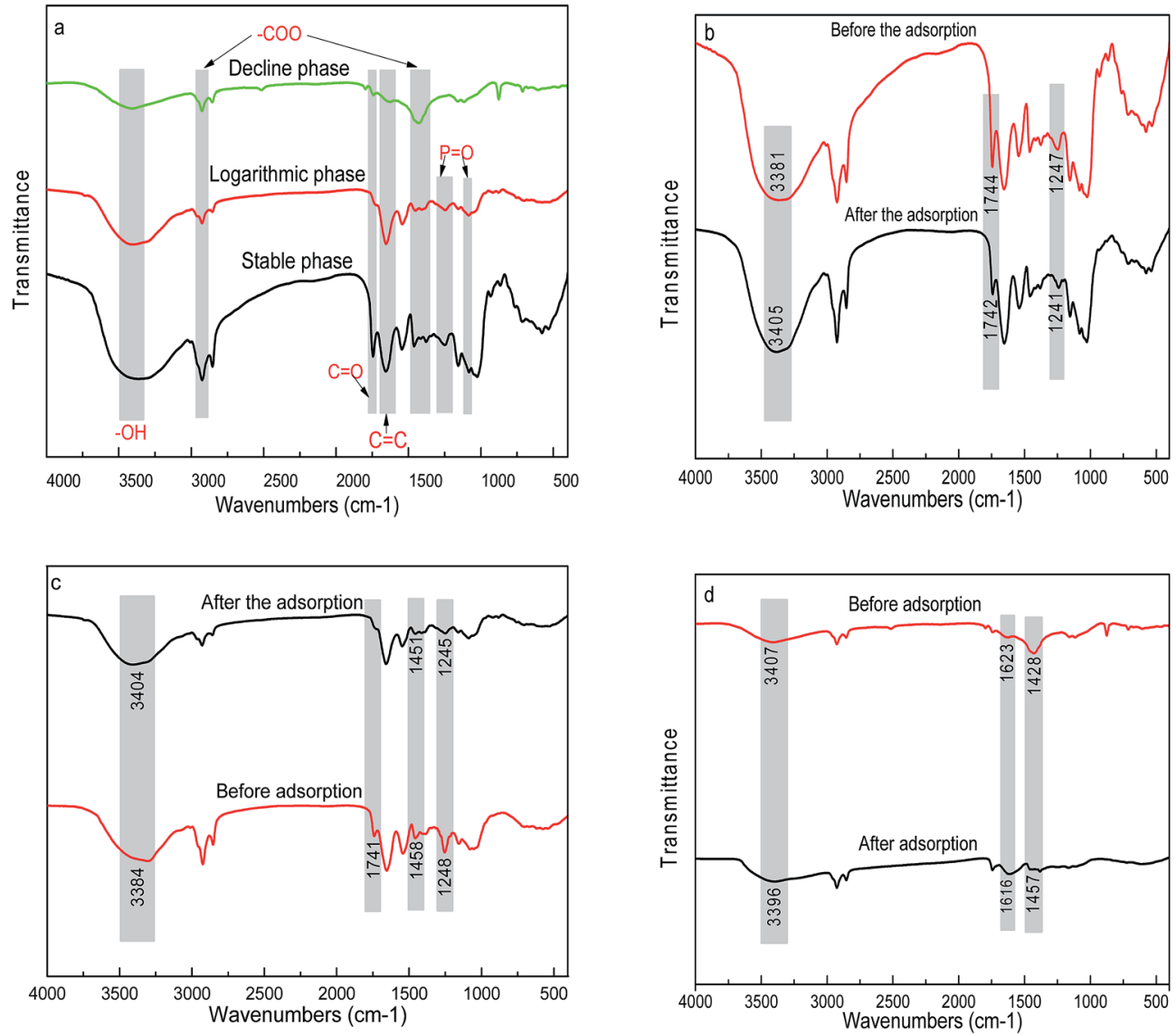

Fig. 5 FT-IR spectra of dried Chlorella sp. QB-102 of each growth phase (a) before adsorption as well as dry biomass of logarithmic phase (b), stable phase (c) and decline phase(d) before and after $\mathrm{Pb}(॥)$ loaded.

be concluded that the growth stages significantly influenced the surface functional groups of algal biomass, which can be attributed to the gradually depletion of the nutrients in the medium with the cultivation time of the serial growth phases. The changes in the functional groups at different growth phases further affected the biosorption capacity of heavy metals.

\subsection{X-ray photoelectron spectroscopy}

To further explore the $\mathrm{Pb}$ (II) biosorption mechanism, the biomass of dried Chlorella sp. QB-102 at three growth phase before and after $\mathrm{Pb}(\mathrm{II})$ loading were analyzed by XPS and shown in Fig. 6. It can be seen from Fig. 6a, the main compositions of the biosorbents for all three stages were $\mathrm{C}, \mathrm{O}$ and $\mathrm{N}$, however, $\mathrm{P}$ for only stable and decline phase, which was consistent with the observation in FT-IR (Fig. 6a). After Pb(II) was adsorbed, two new peaks appeared at the binding energy of $141.4 \mathrm{eV}$ and $136.2 \mathrm{eV}$ for all the samples, which belonged to $\mathrm{Pb} 5 \mathrm{~s}$ and $\mathrm{Pb} 4 \mathrm{f}$, respectively. ${ }^{27}$ Hence, it can be concluded that $\mathrm{Pb}$ was successfully absorbed onto the surface of biomass from all three growth stages.

The high-resolution XPS spectra of $\mathrm{C} 1 \mathrm{~s}$ and $\mathrm{O}$ 1s for dried Chlorella sp. QB-102 biomass of each growth phase before and after $\mathrm{Pb}$ (II) biosorption was shown Fig. 6b and c, respectively. As summarized in Table 4, $\mathrm{C} 1$ peaks were resolved into the following components peaks: and $\mathrm{C}-\mathrm{C}$ and $\mathrm{C}-\mathrm{H}$, around $284 \mathrm{eV}$; $\mathrm{C}-\mathrm{C}=\mathrm{O}$ and $\mathrm{C}-\mathrm{OH}$, around $286 \mathrm{eV} ; \mathrm{O}=\mathrm{C}-\mathrm{OR}$ and $\mathrm{O}=\mathrm{C}-\mathrm{OH}$, 

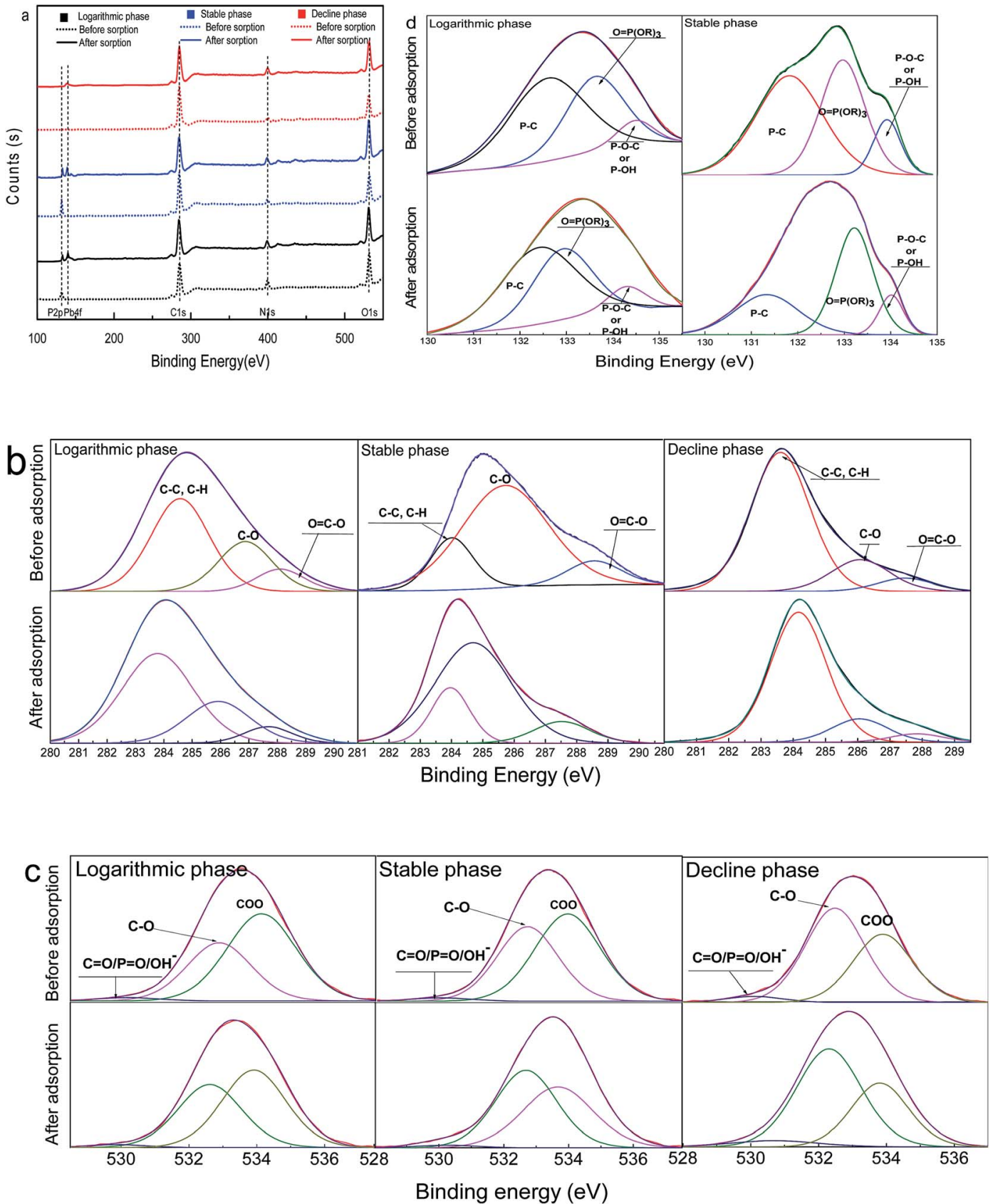

Fig. 6 XPS spectra of dried Chlorella sp. QB-102 biomass of each growth phase (a) as well as the high-resolution XPS spectra of C 1s (b) and O 1s (c) of biomass of each growth phase and $\mathrm{P} 2 \mathrm{p}$ of logarithmic and decline phases (d) before and after $\mathrm{Pb}(॥)$ adsorption.

around $287 \mathrm{eV}$. O1 peaks were also resolved into three component peaks: the small peak at around $529 \mathrm{eV}$ represented $\mathrm{O}=\mathrm{P}-$ $\mathrm{O}^{-}$or $\mathrm{O}=\mathrm{C}-\mathrm{O}^{-}$from phosphate or carboxylate; the strong peak at around $532 \mathrm{eV}$ was associated with $\mathrm{C}-\mathrm{O}-(\mathrm{C}, \mathrm{H}, \mathrm{P})$ in alcohols, acetal, or esters; and the peak at around $534 \mathrm{eV}$ was attributed to $\mathrm{C}-\mathrm{O}$ (carboxyl and ether). ${ }^{28-30}$ In addition, the intensity of carbon peak was considerably decreased while oxygen peak was increased on surface of the metal loaded biosorbents of each growth phase. The quantity of $\mathrm{C}$ in $\mathrm{C}-\mathrm{C}=\mathrm{O} / \mathrm{C}-\mathrm{OH}$ and $\mathrm{O}=\mathrm{C}-$ $\mathrm{OR} / \mathrm{O}=\mathrm{C}-\mathrm{OH}$ was considerably decreased for the biosorbents of each growth phase after $\mathrm{Pb}(\mathrm{II})$ was adsorbed, so did the quantity of $\mathrm{O}$ in $\mathrm{O}=\mathrm{P}-\mathrm{O}^{-} / \mathrm{O}=\mathrm{C}-\mathrm{O}^{-}$. The shift in the binding energies and the decreased area ratio in these groups after $\mathrm{Pb}$ (II) biosorption for the samples of each growth stage was likely to be caused by the binding of lead ions onto the oxygen atoms. It was worth mentioning that the carboxyl groups $\left(\mathrm{COO}^{-}\right)$at around $534 \mathrm{eV}$ was found decreased in the biosorbent- $\mathrm{Pb}$ (II) of stable and decline phase, however, not the logarithmic phase. The observation was consistent with the results of FT-IR.

Fig. 6d was the P 2p XPS spectra for the samples from logarithmic and stable phases before and after $\mathrm{Pb}$ (II) loading. It was noted that both intensity and relative area of $\mathrm{P} 2 \mathrm{p}$ obviously 
Table 4 Summary of binding energies for the adsorbents

\begin{tabular}{|c|c|c|c|c|c|c|c|c|c|c|c|c|c|}
\hline & & \multicolumn{4}{|c|}{ Logarithmic phase } & \multicolumn{4}{|c|}{ Stable phase } & \multicolumn{4}{|c|}{ Decline phase } \\
\hline & & \multicolumn{2}{|c|}{ Biomass } & \multicolumn{2}{|c|}{ Biomass + Pb(II) } & \multicolumn{2}{|c|}{ Biomass } & \multicolumn{2}{|c|}{ Biomass + Pb(II) } & \multicolumn{2}{|c|}{ Biomass } & \multicolumn{2}{|c|}{ Biomass $+\mathrm{Pb}(\mathrm{II})$} \\
\hline & & $E_{\mathrm{B}}(\mathrm{eV})$ & $\%$ & $E_{\mathrm{B}}(\mathrm{eV})$ & $\%$ & $E_{\mathrm{B}}(\mathrm{eV})$ & $\%$ & $E_{\mathrm{B}}(\mathrm{eV})$ & $\%$ & $E_{\mathrm{B}}(\mathrm{eV})$ & $\%$ & $E_{\mathrm{B}}(\mathrm{eV})$ & $\%$ \\
\hline \multirow[t]{2}{*}{ C 1s } & $\mathrm{C}-\mathrm{C}=\mathrm{O} / \mathrm{C}-\mathrm{OH}$ & 286.4 & 31.83 & 286.1 & 20.31 & 285.6 & 41.72 & 285.1 & 23.67 & 286.5 & 17.31 & 286.3 & 10.38 \\
\hline & $\mathrm{O}=\mathrm{C}-\mathrm{OR} / \mathrm{O}=\mathrm{C}-\mathrm{OH}$ & 287.9 & 12.79 & 287.7 & 9.46 & 288.2 & 11.30 & 287.6 & 7.22 & 288.3 & 6.82 & 288.0 & 4.11 \\
\hline \multirow[t]{3}{*}{ O 1s } & $\mathrm{C}=\mathrm{O} / \mathrm{P}=\mathrm{O} / \mathrm{OH}-$ & 529.7 & 2.91 & 529.7 & 1.27 & 529.8 & 4.90 & 529.6 & 2.87 & 529.9 & 4.84 & 530.2 & 3.51 \\
\hline & $\mathrm{C}-\mathrm{O}$ & 532.8 & 43.41 & 532.6 & 44.52 & 532.6 & 42.54 & 532.5 & 47.09 & 532.5 & 63.53 & 532.3 & 67.63 \\
\hline & $\mathrm{COO}^{-}$ & 534.0 & 54.68 & 534.1 & 52.21 & 533.8 & 53.56 & 533.8 & 46.04 & 534.2 & 32.63 & 534.0 & 30.86 \\
\hline \multirow[t]{3}{*}{ P 2p } & $\mathrm{P}-\mathrm{C}$ & 132.5 & 27.28 & 132.4 & 15.97 & 131.7 & 40.91 & 131.3 & 13.57 & & & & \\
\hline & $\mathrm{O}=\mathrm{P}(\mathrm{OR})_{3}$ & 133.6 & 11.66 & 133.6 & 8.65 & 133.3 & 42.05 & 133.3 & 12.99 & & & & \\
\hline & $\mathrm{P}-\mathrm{O}-\mathrm{C} / \mathrm{P}-\mathrm{OH}$ & 134.51 & 5.29 & 134.47 & 2.19 & 134.11 & 17.04 & 134.0 & 5.83 & & & & \\
\hline
\end{tabular}

decreased after biosorption of $\mathrm{Pb}$ (II). It was observed that after $\mathrm{Pb}$ (II) adsorption, the position of $\mathrm{P} 2 \mathrm{p}$ peak shifted to a lower energy, reducing by 0.89 and $0.80 \mathrm{eV}$ respectively for logarithmic and stable phases, indicating that the relevant chemical reaction occurred between $\mathrm{Pb}$ (II) and the biosorbents from stable and decline growth phase during the biosorption process. The $\mathrm{P}$ $2 \mathrm{p}$ spectra can be decomposed into three components 131.50, 133.00 and $134.20 \mathrm{eV}$, which can be assigned to $\mathrm{P}-\mathrm{C}, \mathrm{O}=\mathrm{P}(\mathrm{OR})_{3}$ and $\mathrm{P}-\mathrm{O}-\mathrm{C}$ (phosphate), ${ }^{31-33}$ respectively. The relative area ratio of the three P-binded functional groups considerably reduced for the biosorbents from both exponential and stable phases after $\mathrm{Pb}$ (II) was adsorbed, indicating that all the phosphorus functional groups involved in the complexation reactions with $\mathrm{Pb}^{2+}$.

\subsection{Potentiometric titration}

The species and concentrations of functional groups on the surface of dried Chlorella sp. QB-102 biomass of each growth phase were determined by PT. The $\mathrm{p} K$ values, site densities (mol $\mathrm{kg}_{\mathrm{dw}}{ }^{-1}$ ) and corresponding functional groups were summarized in Table 5. The first $\mathrm{p} K$ was attributed to the carboxyl groups ( $\mathrm{p} K$ $=2-6) .{ }^{14,15}$ The $\mathrm{p} K_{2}$ and $\mathrm{p} K_{3}$ were at around $\mathrm{pH} 6.7$ and $\mathrm{pH} 8.7$, which can be attributed to the phosphoric ( $\mathrm{p} K=5.6-7.2)$ and amine groups ( $\mathrm{p} K=8.6-9.0)$ that exist in the form of bioorganic molecules on the cell wall of microalgae. The $\mathrm{p} K_{4}$ appeared at around $\mathrm{pH} 10$ and this buffering capacity is usually attributed to hydroxyl functional groups on the algal surface. The predominant functional groups for three growth phases observed were in agreement with the result of FT-IR, and they are all the active sites for $\mathrm{Pb}$ (II) binding. It was worth noted that the phosphoryl functional groups were not found in biomass of decline phase, which was consistent with the observations of FT-IR and XPS. It might be because the depletion of phosphorus after the longtime incubation during the decline phase.

For the four sites, the binding site densities were estimated to be $0.39,0.19,0.21$ and $2.95 \mathrm{~mol} \mathrm{~kg}^{-1}$ for logarithmic phase; $0.27,0.22,0.23,3.07 \mathrm{~mol} \mathrm{~kg}^{-1}$ for stable phase, respectively. While for the decline phase, $0.15,0.22,1.81 \mathrm{~mol} \mathrm{~kg}^{-1}$ for carboxyl, amine and hydroxyl functional groups, respectively. In addition, the decline phase showed the lowest total sites concentrations, which was largely attributed to the lack of phosphoric functional groups and the lower hydroxyl functional groups. Although the carboxyl and hydroxyl functional groups were involved in the $\mathrm{Pb}(\mathrm{II})$ binding as aforementioned, the lowest total sites concentrations caused the lowest biosorption capacity of $\mathrm{Pb}$ (II) biosorption.

It was noted that the total surface functional groups showed no significant differences between the biomass of logarithmic phase and stable phase. However, as for the effective active sites for $\mathrm{Pb}(\mathrm{II})$ binding, the carboxyl groups were found more in stable phase than that in logarithmic phase as stated in FT-IR and XPS analysis. Indeed, the extra effective carboxyl groups contributing to the $\mathrm{Pb}$ (II) binding at the stable growth stage (Fig. 5, 6 and Table 4) might be attributed to the presence of galacturonic acid on the surface of microalgal biomass, ${ }^{14}$ which tended to increase with growth phase and decreased after stationary phase, ${ }^{34}$ leading to the higher biosorption capacity of biomass from stable growth phase. Also, the higher

Table 5 Titration results of biosorbents calculated with Protofit $\left(\mathrm{mol} \mathrm{kg}^{-1}\right)^{a}$

\begin{tabular}{|c|c|c|c|c|c|c|c|c|c|}
\hline Growth phase & $\mathrm{p} K_{1}$ & $\mathrm{C} 1$ & $\mathrm{p} K_{2}$ & $\mathrm{C} 2$ & $\mathrm{p} K_{3}$ & $\mathrm{C} 3$ & $\mathrm{p} K_{4}$ & $\mathrm{C} 4$ & $\mathrm{C}_{\text {tot }}$ \\
\hline Logarithmic phase & $6.78 \pm 0.11$ & $0.19 \pm 0.11$ & $4.04 \pm 0.06$ & $0.39 \pm 0.07$ & $8.73 \pm 0.15$ & $0.21 \pm 0.03$ & $10.37 \pm 0.09$ & $2.95 \pm 0.06$ & $3.74 \pm 0.05$ \\
\hline Stable phase & $6.61 \pm 0.13$ & $0.22 \pm 0.08$ & $3.98 \pm 0.05$ & $0.27 \pm 0.08$ & $8.78 \pm 0.10$ & $0.23 \pm 0.06$ & $9.79 \pm 0.20$ & $3.07 \pm 0.10$ & $3.79 \pm 0.11$ \\
\hline Fundamental & Phosphoryl & & Carboxyl & & Amine & & Hydroxyl & & \\
\hline
\end{tabular}

groups

${ }^{a}$ ND: not detected. 
concentration of hydroxyl and phosphoryl in the surface of biomass from stable phase than that from logarithmic phase further contributed to the larger $\mathrm{Pb}$ (II) biosorption capacity. Given that the algal cells of stable growth stage had the highest biomass concentration, it was recommended that stable phase biomass can be harvested as biosorbents for heavy metal removal.

\section{Conclusions}

The algal dry biomass from each growth phase represented highly efficient removal of $\mathrm{Pb}$ (II) from water with the highest $\mathrm{Pb}$ (II) biosorption capacity of $298.17 \mathrm{mg} \mathrm{g}^{-1}$ at stable phase. The experimental data were well fitted with the pseudo-second-order kinetics and Freundlich isotherm models. The FT-IR, XPS and PT analysis showed that the more effective active sites in carboxyl, and higher sites concentrations of hydroxyl and phosphoryl functional groups contributed to the largest biosorption capacity of biomass from stable phase. Thus, the stable phase biomass can be used as an efficient, and inexpensive and environment-friendly biosorbent for heavy metal removal.

\section{Acknowledgements}

This work was financially supported by the China Postdoctoral Science Foundation (Grant No. 2015M580671; 2016T90738), the National Natural Science foundation of China (Grant No. 51604207) and the Independent Innovation Foundation of Wuhan University of Technology (Grant No. 173208001).

\section{References}

1 M. V. Subbaiah, G. Yuvaraja, Y. Vijaya and A. Krishnaiah, J. Taiwan Inst. Chem. Eng., 2011, 42, 965-971.

2 Y. Liu, Q. Zhao, G. Cheng and H. Xu, Chem. Eng. J., 2011, 173, 792-800.

3 H. Chen, J. Zhao, G. Dai, J. Wu and H. Yan, Desalination, 2010, 262, 174-182.

4 A. Çelekli, M. Yavuzatmaca and H. Bozkurt, J. Hazard. Mater., 2010, 173, 123-129.

5 F. V. Hackbarth, F. Girardi, S. M. A. G. U. de Souza, A. A. U. de Souza, R. A. R. Boaventura and V. J. P. Vilar, Chem. Eng. J., 2013, 242, 294-305.

6 D. Bulgariu and L. Bulgariu, Bioresour. Technol., 2012, 103, 489-493.

7 M. Mohan and S. K. Dubey, Ecotoxicol. Environ. Saf., 2013, 98, 1-7.

8 L. Bulgariu, M. Lupea, D. Bulgariu, C. Rusu and M. Macoveanu, Environ. Eng. Manage. J., 2013, 12, 183-190.

9 D. Bulgariu and L. Bulgariu, J. Cleaner Prod., 2015, 1-9.

10 J. He, A. Liu and J. Paul Chen, J. Colloid Interface Sci., 2015, 439, 162-169.
11 R. Y. Stanier, R. Kunisawa, M. Mandel and G. Cohen-Bazire, Bacteriol. Rev., 1971, 35, 171-205.

12 M. K. Ji, R. A. I. Abou-Shanab, S. H. Kim, E. S. Salama, S. H. Lee, A. N. Kabra, Y. S. Lee, S. Hong and B. H. Jeon, Ecological Engineering, 2013, 58, 142-148.

13 W. Peng, H. Li, Y. Liu and S. Song, J. Mol. Liq., 2016, 221, 8287.

14 S. Hadjoudja, V. Deluchat and M. Baudu, J. Colloid Interface Sci., 2010, 342, 293-299.

15 L. Xia, H. Li and S. Song, J. Appl. Phycol., 2016, 28, 391-407. 16 X. Zhang, P. Amendola, J. C. Hewson, M. Sommerfeld and Q. Hu, Bioresour. Technol., 2012, 116, 477-484.

17 H. B. Senturk, D. Ozdes and C. Duran, Desalination, 2010, 252, 81-87.

18 N. Masoudzadeh, F. Zakeri, T. b. Lotfabad, H. Sharafi, F. Masoomi, H. S. Zahiri, G. Ahmadian and K. A. Noghabi, J. Hazard. Mater., 2011, 197, 190-198.

19 U. F. Umar, M. A. Khan, M. Athar and J. A. Kozinski, Chem. Eng. J., 2011, 171, 400-410.

20 N. Barka, M. Abdennouri, A. Boussaoud and M. EL Makhfouk, Desalination, 2010, 258, 66-71.

21 F. Deniz and S. D. Saygideger, Bioresour. Technol., 2010, 101, 5137-5143.

22 Y. Zhou, P. Lu and J. Lu, Carbohydr. Polym., 2012, 88, 502508.

23 T. Y. Jiang, J. Jiang, R. K. Xu and Z. Li, Chemosphere, 2012, 89, 249-256.

24 P. Sarwa and S. K. Verma, Clean: Soil, Air, Water, 2014, 42, 1298-1303.

25 G. Blázquez, M. A. Martín-Lara, E. D. Ruiz, G. Tenorio and M. Calero, J. Ind. Eng. Chem., 2012, 18, 1741-1750.

26 M. Mecozzi, M. Pietroletti and A. Tornambé, Spectrochim. Acta, Part A, 2011, 78, 1572-1580.

27 H. Cui, J. Chen, H. Yang, W. Wang, Y. Liu, D. Zou, W. Liu and G. Men, Chem. Eng. J., 2013, 232, 372-379.

28 C. Bertagnolli, A. Uhart, J. C. Dupin, M. G. C. da Silva, E. Guibal and J. Desbrieres, Bioresour. Technol., 2014, 164, 264-269.

29 P. Sun, C. Hui, S. Wang, L. Wan, X. Zhang and Y. Zhao, Colloids Surf., B, 2016, 139, 164-170.

30 X. Xu, A. Schierz, N. Xu and X. Cao, J. Colloid Interface Sci., 2016, 463, 55-60.

31 J. Wu, C. Jin, Z. Yang, J. Tian and R. Yang, Carbon, 2015, 82, 562-571.

32 Z. Zheng, L. Qiang, T. Yang, B. Wang, X. Cui and H. Wang, J. Polym. Res., DOI: 10.1007/s10965-014-0443-2.

33 F. Xiao, K. Wang and M. S. Zhan, J. Mater. Sci., 2012, 47, 4904-4913.

34 R. L. Soon, R. L. Nation, S. Cockram, J. H. Moffatt, M. Harper, B. Adler, J. D. Boyce, I. Larson and J. Li, J. Antimicrob. Chemother., 2011, 66, 126-133. 